\title{
Cytochrome oxidase subunit 2 gene allows simultaneous detection and typing of Trypanosoma rangeli and Trypanosoma cruzi
}

\author{
Amanda Regina Nichi de Sá ', Mário Steindel², Lara Maria Kalempa Demeu', Débora Denardin Lückemeyer², \\ Edmundo Carlos Grisard², Quirino Alves de Lima Neto³, Silvana Marques de Araújo', \\ Max Jean de Ornelas Toledo ${ }^{1}$ and Mônica Lúcia Gomes ${ }^{1 *}$
}

\begin{abstract}
Background: The parasites Trypanosoma rangeli and Trypanosoma cruzi share vectors and hosts over a wide geographical area in Latin America. In this study, we propose a single molecular approach for simultaneous detection and typing of T. rangeli and T. cruzi.

Methods: A restriction fragment length polymorphism analysis of the mitochondrial cytochrome oxidase II gene (COII-RFLP) using enzyme Alul and different amounts of DNA from the major genetic groups of T. rangeli and T. cruzi (KP1+/KP1- and DTU-I/DTU-II) was carried out. The same marker was tested on the other T. cruzi DTUs (DTU-III to DTU-VI) and on DNA extracted from gut contents of experimentally infected triatomines.

Results: The COII PCR generates a 400 bp fragment, which after digestion with Alul (COII-RFLP) can be used to distinguish T. rangeli from T. cruzi and simultaneously differentiate the major genetic groups of T. rangeli (KP1+ and KP1-) and T. cruzi (DTU-I and DTU-II). The COII-RFLP generated bands of $\sim 120$ bp and 280 bp for KP1+, whereas for KP1- no amplicon cleavage was observed. For T. cruzi, digestion of COIl revealed a 300 bp band for DTU-I and a 250 bp band for DTU-II. For DTU-III to DTU-VI, COII-RFLP generated bands ranging from 310 to 330 bp, but the differentiation of these DTUs was not as clear as the separation between DTU-I and DTU-II. After Alul digestion, a species-specific fragment of $\sim 80$ bp was observed for all DTUs of T. cruzi. No cross-amplification was observed for Leishmania spp., T. vivax or T. evansi.
\end{abstract}

Conclusions: The COII-RFLP allowed simultaneous detection and typing of T. rangeli and T. cruzi strains according to their major genetic groups (KP1+/KP1- and DTU-I/DTU-II) in vitro and in vivo, providing a reliable and sensitive tool for epidemiological studies in areas where T. rangeli and T. cruzi coexist.

Keywords: Trypanosoma rangeli, Trypanosoma cruzi, Cytochrome oxidase subunit 2 gene, Diagnosis, Typing

\section{Background}

Trypanosoma rangeli and Trypanosoma cruzi are protozoan parasites that infect sylvatic and domestic mammals and humans in several Central and South American countries $[1,2]$. T. rangeli is considered nonpathogenic to mammals, while $T$. cruzi, the causative agent of Chagas disease, affects around 7 to 8 million people in Latin America,

\footnotetext{
*Correspondence: mlgomes@uem.br

'Departamento de Ciências Básicas da Saúde, Universidade Estadual de Maringá (UEM), Av. Colombo, 5790, Zona 7. CEP: 87020-900, Maringá, Paraná, Brazil

Full list of author information is available at the end of the article
}

leading to morbidity or mortality [3-5]. Since these parasites share a variety of soluble antigens, vectors, and hosts over a wide geographical area, mixed infections in triatomines and mammals may occur [6,7], reinforcing the need for specific diagnosis [3,4,8-13].

Several nuclear and mitochondrial molecular markers have been used for detection and differentiation of T. rangeli and $T$. cruzi $[9,14-19]$, but none of them allows typing of strains according to the currently described genotypes. The sequence variability of the kinetoplast DNA (kDNA) minicircle was used to classify T. rangeli strains into two major genetic groups, termed 
KP1+ and KP1- [20-22], which were further confirmed by others $[4,23]$.

Assessment of $T$. rangeli genetic variability is based on studies of one or a few nuclear or mitochondrial markers [2,23-26], which indicate the intraspecific genetic variability of this parasite and confirm the KP1+ and KP1genetic groups [21,22].

Differently from $T$. rangeli, the genomic plasticity of T. cruzi is well described in the literature [6,8,27-37]. Strains of this parasite have been classified in six discrete typing units or DTUs (DTU-I to DTU-VI), which were further divided into subtypes by several authors [29,38,39], and a recent genotype identified as TcBat $[35,36,40]$.

Restriction fragment length polymorphism (RFLP) analysis of the mitochondrial cytochrome oxidase II (COII) subunit 2 gene, termed COII-RFLP, was originally proposed by Freitas et al. [30] and modified by Abolis et al. [7] to distinguish T. cruzi DTUs isolated from southern Brazil. This method has not yet been used to detect and type $T$. rangeli strains. In this study, considering the sympatric occurrence in mammals and vectors and the genetic plasticity of T. rangeli and T. cruzi, we used COII-RFLP as a single molecular approach for simultaneous detection and typing of these two parasites.

\section{Methods}

\section{Parasites}

Parasite strains used in this study are shown in Table 1. T. rangeli $\mathrm{KP} 1+$ and $\mathrm{KP} 1$ - strains were characterized according to the methodology of Vallejo et al. [21]. T. cruzi DTUs were the standard strains described by Zingales et al. [35,36].

\section{Genomic DNA extraction and quantification}

$T$. rangeli DNA was extracted by the standard phenolchloroform method, and T. cruzi DNA was extracted as previously described [41]. DNA from Leishmania amazonensis, Leishmania braziliensis, Leishmania infantum, Trypanosoma evansi and Trypanosoma vivax was extracted by the standard phenol-chloroform method and used as controls. Extracted DNA was eluted in TE buffer (10 mM Tris-HCl pH 8.0 and 1 mM EDTA pH 8.0), quantified by spectrophotometry at $260 / 280 \mathrm{~nm}$, and stored at $-20^{\circ} \mathrm{C}$ until use.

\section{COII-RFLP analysis}

Amplification of the COII gene by PCR following restriction fragment length polymorphism analysis with AluI (COII-RFLP) was used to simultaneously detect and differentiate strains of $T$. rangeli $(\mathrm{KP} 1+/ \mathrm{KP} 1-)$ and T. cruzi (DTU-I to DTU-VI).

COII amplification was carried out as described by Freitas et al. [30] with modifications proposed by Abolis et al. [7]. Briefly, each amplification reaction was performed in a final volume of $15 \mu \mathrm{L}$, containing $3.1 \mathrm{pmol}$ of primers Tcmit-10 (5'-CCA TAT ATT GTT GCA TTA TT-3') and Tcmit-21 (5' ${ }^{\prime}$ TTG TAA TAG GAG TCA TGT TT-3'), 2 ng of DNA (ideal amount for amplification in relation to the tested amounts, from $0.1 \mathrm{fg}$ to $2 \mathrm{ng}), 2.5 \mu \mathrm{M}$ of $\mathrm{dNTP}, 3.5 \mathrm{mM}$ of $\mathrm{MgCl}_{2}$, and $1 \mathrm{U}$ of Platinum Taq DNA polymerase (Invitrogen) in the buffer provided by the manufacturer. Amplification was processed in a Techne TC-512 thermocycler with initial denaturation at $94^{\circ} \mathrm{C}$ for $1 \mathrm{~min}$, followed by 30 cycles $\left(94^{\circ} \mathrm{C}\right.$ for $30 \mathrm{~s}, 48^{\circ} \mathrm{C}$ for $2 \mathrm{~min}$, and $72^{\circ} \mathrm{C}$ for $2 \mathrm{~min}$ ) and a final extension step at $72^{\circ} \mathrm{C}$ for $10 \mathrm{~min}$. Ten microliters of unpurified amplification product was digested with $10 \mathrm{U}(1 \mu \mathrm{L})$ of the AluI restriction enzyme (New England BioLabs) in the buffer $(1 \mu \mathrm{L})$ provided by the manufacturer for $16 \mathrm{~h}$ at $37^{\circ} \mathrm{C}$. From artificial mixtures of DNA of the four major genetic groups processed simultaneously in a single reaction, the groups DTU-I, DTU-II and KP1+ were considered an internal control of enzymatic digestion. The resulting fragments were analyzed in $6 \%$ polyacrylamide gel, silver-stained and digitally recorded.

\section{T. rangeli COIl gene sequencing and comparative sequence analysis}

The $T$. rangeli COII gene fragment $(\sim 400 \mathrm{bp})$ amplified by PCR from $T$. rangeli Choachí and SC-58 strains was cloned in the $\mathrm{pGEM}^{\ominus}-\mathrm{T}$ Easy Vector System plasmid (Promega) and transformed in Escherichia coli DH5 $\alpha$ competent bacteria by heat shock according to standard protocols. After culture for $16-18 \mathrm{~h}$ at $37^{\circ} \mathrm{C}$ on LuriaBertani medium (LB), three positive clones were subjected to recombinant DNA extraction by the CTAB (cetyltrimethylammonium bromide) method [42] and checked by PCR for the presence of the insert. The plasmid inserts of the three clones had both strands sequenced using the DYEnamic ${ }^{\mathrm{TM}}$ ET Terminator Kit, using M13 primers in a MegaBACE 1000 sequencer (GE Healthcare). The sequences obtained were assembled and analyzed using the Phred/Phrap/Consed package [43] following comparison of all high-quality sequences (Phred $>20$ ) with public databases using the BLAST routine. Sequences of the COII gene from T. cruzi Sylvio [GenBank: EU302222.1], Esmeraldo [GenBank: AF359035.1], 231 [GenBank: DQ343720.1], CAN III [GenBank: AF359030.1], SO3 cl5 [GenBank: AF359039.1] and CL Brener [GenBank: AF359041.1] strains were retrieved from GenBank. Multiple alignments of nucleotide sequences were performed using ClustalW software [44], and alignment was trimmed by using the BioEdit software [45]. COII sequences from T. rangeli Choachí and SC-58 strains were deposited in GenBank under accession numbers HQ691249.1 and HQ691248.1, respectively. 
Table 1 Trypanosomatid species and strains used in this study, their original hosts, geographical origins and genetic groups

\begin{tabular}{|c|c|c|c|c|}
\hline Species & Strain & Hosts & Geographical origin* & Genetic group ${ }^{* *}$ \\
\hline \multirow[t]{10}{*}{ Trypanosoma cruzi } & Sylvio X10 & Homo sapiens & Brazil (PA) & DTU-I \\
\hline & Esmeraldo $\mathrm{cl} 3$ & H. sapiens & Brazil (BA) & DTU-II \\
\hline & 231 & H. sapiens & Brazil (MG) & DTU-III \\
\hline & CAN III & H. sapiens & Brazil (PA) & DTU-IV \\
\hline & SO3 cl5 & Triatoma infestans & Bolivia & DTU-V \\
\hline & CL Brener & T. infestans & Brazil (RS) & DTU-VI \\
\hline & 150 & H. sapiens & Brazil (MG) & DTU-I \\
\hline & 328 & H. sapiens & Brazil (PR) & DTU-\| \\
\hline & SC-90 & Didelphis aurita & Brazil (SC) & DTU-I \\
\hline & SC-95 & H. sapiens & Brazil (SC) & DTU-II \\
\hline \multirow[t]{17}{*}{ Trypanosoma rangeli } & Choachí & Rhodnius prolixus & Colombia & $\mathrm{KP} 1+$ \\
\hline & H8GS & H. sapiens & Colombia & $\mathrm{KP} 1+$ \\
\hline & San Agostín & H. sapiens & Colombia & $\mathrm{KP} 1+$ \\
\hline & D3493 & R. prolixus & Colombia & $\mathrm{KP} 1+$ \\
\hline & $\mathrm{H} 14$ & H. sapiens & Honduras & $\mathrm{KP} 1+$ \\
\hline & $\mathrm{H} 9$ & H. sapiens & Honduras & KP1+ \\
\hline & Macias & H. sapiens & Venezuela & $\mathrm{KP} 1+$ \\
\hline & Palma 2 & R. prolixus & Venezuela & $\mathrm{KP} 1+$ \\
\hline & R1625 & H. sapiens & El Salvador & $\mathrm{KP} 1+$ \\
\hline & B450 & Rhodnius robustus & Brazil (PA) & $\mathrm{KP} 1+$ \\
\hline & 1545 & R. prolixus & Colombia & $\mathrm{KP} 1+$ \\
\hline & SC-58 & Echimys dasythrix & Brazil (SC) & KP1- \\
\hline & SC-61 & E. dasythrix & Brazil (SC) & KP1- \\
\hline & SC-68 & Panstrongylus megistus & Brazil (SC) & KP1- \\
\hline & SC-74 & P.megistus & Brazil (SC) & KP1- \\
\hline & SC-75 & P.megistus & Brazil (SC) & KP1- \\
\hline & C-23 & Aotus trivirgatus & Colombia & KP1- \\
\hline Trypanosoma evansi & Te & Canis familiaris & Brazil (RS) & NA \\
\hline Trypanosoma vivax & Tv & Bos taurus & Brazil (PB) & NA \\
\hline Leishmania amazonensis & M2269 & H. sapiens & Brazil (PA) & NA \\
\hline Leishmania braziliensis & M2903 & H. sapiens & Brazil (PR) & NA \\
\hline Leishmania infantum & LRM75 & H. sapiens & Brazil (PI) & NA \\
\hline
\end{tabular}

* Letters in parentheses indicate the Brazilian state where the strain was isolated (BA, Bahia; MG, Minas Gerais; PA, Pará; RS, Rio Grande do Sul; SC, Santa Catarina). ** DTU-I to DTU-VI are the different $T$. cruzi DTUs (Discrete Typing Units) described by Zingales et al. [35,36], and KP1+/KP1- are the T. rangeli genetic groups described by Vallejo et al. [21]. NA -Not Applicable.

Targeting the COIl gene: Detection and characterization of $T$. rangeli and $T$. cruzi by PCR

The COII-RFLP for detecting and typing $T$. rangeli (KP1+/KP1) and T. cruzi (DTU-I/DTU-II) was tested in vitro with DNA of each genetic group and in artificial mixtures of DNA in the ratios 1:1 to 1:9 (corresponding to amounts from $2 \mathrm{ng}$ to $0.02 \mathrm{ng}$ ) and in vivo in triatomines, simulating natural infections. Groups of ten fifthinstar Rhodnius prolixus were experimentally infected using an artificial feeding apparatus, using pure or mixed culture-derived epimastigotes from the T. cruzi SC-90 (DTU-I) and SC-95 (DTU-II), T. rangeli Choachí (KP1+) and SC-58 (KP1-) strains, in the following combinations: DTU-I or DTU-II alone, KP1(+) and KP1(-) alone, DTU-I + KP1(+), DTU-I + KP1(-), DTU-II + KP1(+), DTU$\mathrm{II}+\mathrm{KP} 1(-), \mathrm{DTU}-\mathrm{I}+\mathrm{DTU}-\mathrm{II}+\mathrm{KP} 1(+), \mathrm{DTU}-\mathrm{I}+\mathrm{DTU}-\mathrm{II}+$ $\mathrm{KP} 1(-), \mathrm{DTU}-\mathrm{I}+\mathrm{KP} 1(+)+\mathrm{KP} 1(-), \mathrm{DTU}-\mathrm{II}+\mathrm{KP} 1(+)+$ $\mathrm{KP} 1(-)$, and DTU-I + DTU-II + KP1(+) + KP1(-). After 30 to 45 days of the infective meal, the midgut and hindgut of five insects were removed and total DNA 
was extracted as described by Macedo et al. [41]. For the other T. cruzi DTUs (DTU-III to VI), the performance of the COII-RFLP assay was not tested with artificial or natural mixed infections.

As an external control to compare the efficiency of COII-RFLP in separating T. cruzi DTU-I from DTU-II and $T$. rangeli $\mathrm{KP} 1+$ from $\mathrm{KP} 1-$, the ribosomal RNA (rRNA) gene from the same samples was amplified, using a multiplex PCR reaction as described by Souto et al. [17].

\section{Results}

Amplification of the COII gene from all T. cruzi strains representing the six DTUs and from all $T$. rangeli strains representing the two major genetic groups (KP1+ and KP1-) revealed the expected band of $\sim 400 \mathrm{bp}$ (Figure 1A). Digestion of the amplified fragments with AluI generated the RFLP profile shown in Figure 1B. Regardless of DTU, an 80 bp band was observed for all $T$. cruzi strains; this band was absent in T. rangeli. Except for T. cruzi DTU-III, DTU-V and DTU-VI, digestion products ranging from 250 to $330 \mathrm{bp}$ allowed the DTU-I, DTU-II and DTU-IV strains to be distinguished (Figure 1B). Digestion of COII amplicon from T. rangeli $\mathrm{KP} 1+$ strains generated restriction fragments of approximately 125 and $280 \mathrm{bp}$, while the amplicons from all KP1- strains still consisted of $400 \mathrm{bp}$, indicating that they were not digested by AluI (Figure 1B). No amplification of the COII gene was observed for T. evansi, T. vivax, L. amazonensis, L. braziliensis and $L$. infantum (Figure 1A, 1B).

The absence of cleavage of the COII gene for T. rangeli KP1- strains was further investigated by sequencing and comparative analysis of the amplification products. Multiple sequence analysis was carried out using the COII gene from T. rangeli Choachí (377 bp) and SC-58 (375 bp) strains, and T. cruzi COII gene sequences retrieved from GenBank. Sequences of the T. rangeli COII gene from Choachí (KP1+) and SC-58 (KP1-) strains were $95.2 \%$ similar to each other, showing 15 nucleotide substitutions, an insertion (CTT) on positions 48-50 for the Choachí strain, and the absence of the AluI cleavage site in the SC-58 strain (positions 113-116), which was present in the Choachí strain (Figure 2). The interspecific analysis of COII gene sequences showed similarities between $T$. rangeli and T. cruzi. The number of single nucleotide polymorphisms (SNPs) between T. cruzi DTU-I and DTU-II strains (90.6\% similarity) was twice that observed between $T$. rangeli $\mathrm{KP} 1+$ and $\mathrm{KP} 1$ - strains. T. rangeli $\mathrm{KP} 1+$ exhibited a similarity of $85.9 \%$ with DTU-I and $85.1 \%$ with DTU-II, whereas KP1- showed $85.0 \%$ similarity with DTU-I and $84.2 \%$ with DTU-II.

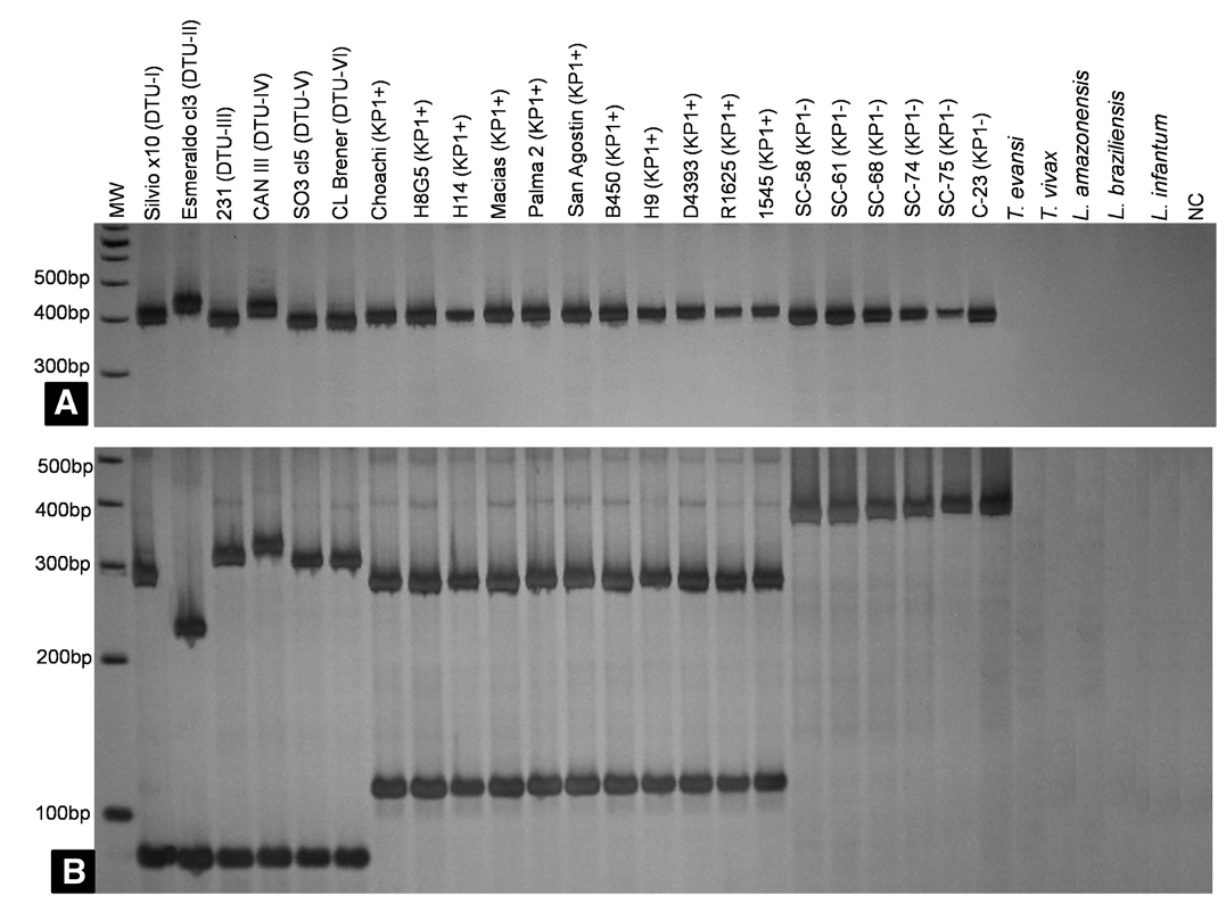

Figure 1 COIl gene assayed from Trypanosoma cruzi, Trypanosoma rangeli and other trypanosomatids (Table 1). A) COIl gene amplification products from T. cruzi (lines 1 to 6), T. rangeli (lines 7 to 23); B) RFLP pattern obtained by Alul digestion of the cytochrome oxidase subunit II (COII) gene from T. cruzi (DTU-I to DTU-VI) strains and T. rangeli (KP1+ and KP1-) resolved in 6\% polyacrylamide gel stained with silver nitrate. MW $=100 \mathrm{bp}$ DNA Ladder (Invitrogen), NC = Negative control (No DNA added). 


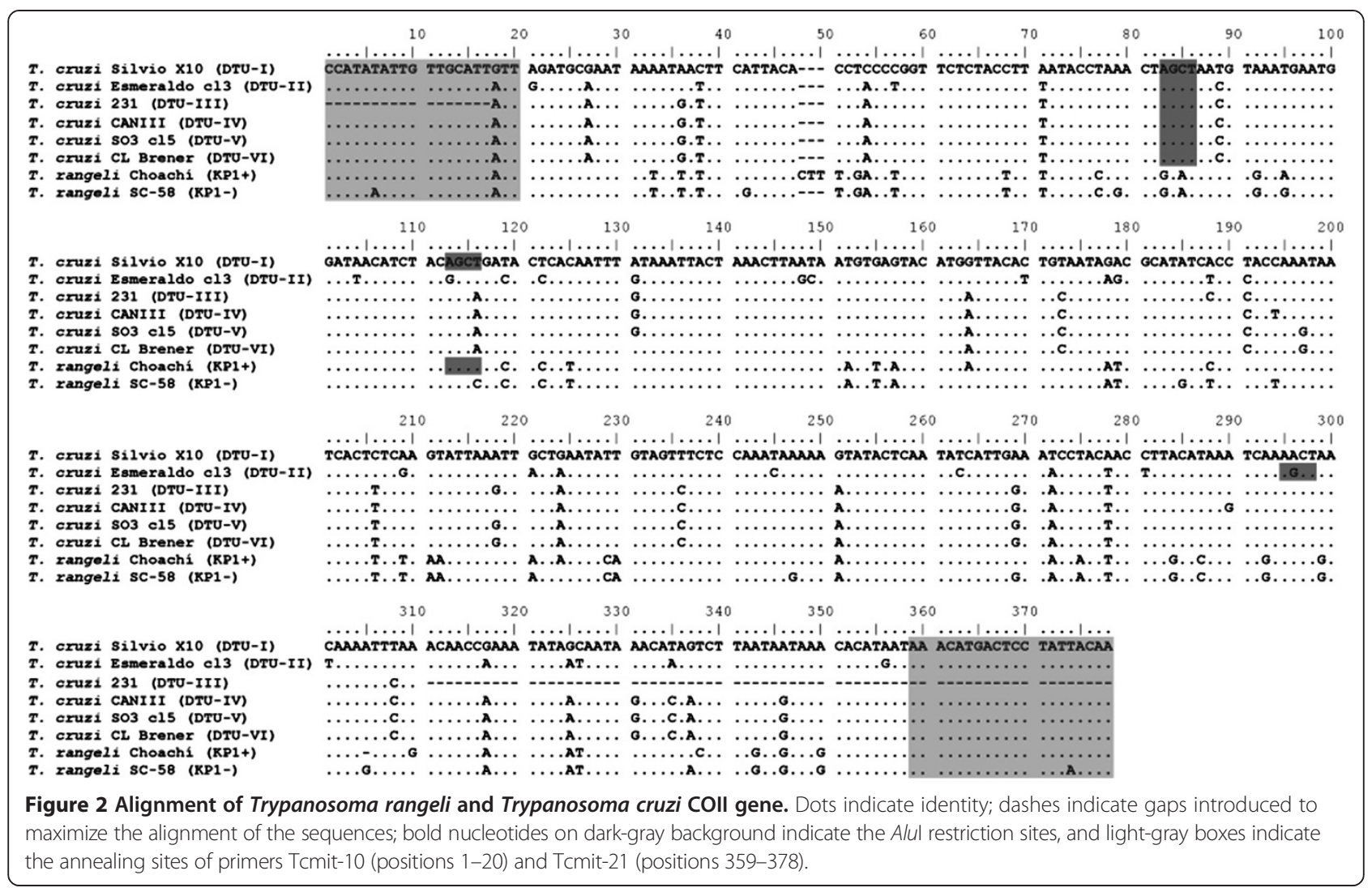

The COII-RFLP allowed detection and typing of $T$. rangeli and $T$. cruzi strains in artificial DNA mixtures; as little as $0.02 \mathrm{ng}$ of DNA from both parasites could be detected (Figure 3). For this purpose, detection and typing of parasites present in the intestinal tracts of experimentally infected triatomines were also performed by COII-RFLP, with interesting results. As shown in Figure 4, a clear differentiation between $T$. rangeli and $T$. cruzi was achieved, as well as typing of these parasites according to their major genetic groups. The $T$. cruzi diagnostic band ( $~ 80 \mathrm{bp})$ observed in the COII-RFLP using extracted DNA from each parasite and genetic group was also present in the assay performed with the gut contents from experimentally infected triatomines, revealing the usefulness of the method. Even when T. rangeli (KP1+ and KP1-) and T. cruzi (DTU-I and DTU-II) are present in the same triatomine, which is commonly observed in nature, it is possible to identify each individual parasite species and genetic group.

The multiplex rRNA PCR was also able to detect and distinguish T. cruzi DTU-I (260 bp) and DTU-II (300 bp) strains in both reconstitution tests (artificial DNA mixture) and in the experimentally infected triatomines. For the $T$. rangeli strains, a single band of $\sim 210$ bp was observed for both KP1+ and KP1- genotypes (data not shown), in contrast to COII-RFLP, which distinguished these two genetic groups.

\section{Discussion and conclusions}

The COII-RFLP described in this study allows specific detection of $T$. rangeli and $T$. cruzi, even in mixed infections, as well as assessment of their major genetic groups circulating in Latin America, i.e., KP1+/KP1- for T. rangeli and DTU-I/DTU-II for $T$. cruzi $[46,47]$. This assay was also tested using DNA from kinetoplastids of different species (L. braziliensis, L. amazonensis, L. infantum, T. vivax and T. evansi), with negative results on PCR, confirming that the COII primers are specific for $T$. cruzi and $T$. rangeli. Other Leishmania species of medical and epidemiological importance such as those belonging to the L. guyanensis complex, as well as L. naiffi and L. lainsoni remain to be evaluated. However, considering the different organization of the Leishmania sp. maxicircles compared to Trypanosoma spp. and the results obtained for L. braziliensis, L. amazonensis and L. infantum, we should expect no cross-amplification.

The COII-RFLP, similar to the multiplex PCR targeting rRNA proposed by Souto et al. [17], is able to differentiate T. cruzi DTU-I, DTU-II and T. rangeli, with the additional advantage of distinguishing the parasite's KP1+ and KP1genotypes. However, in artificial mixtures where DNA 


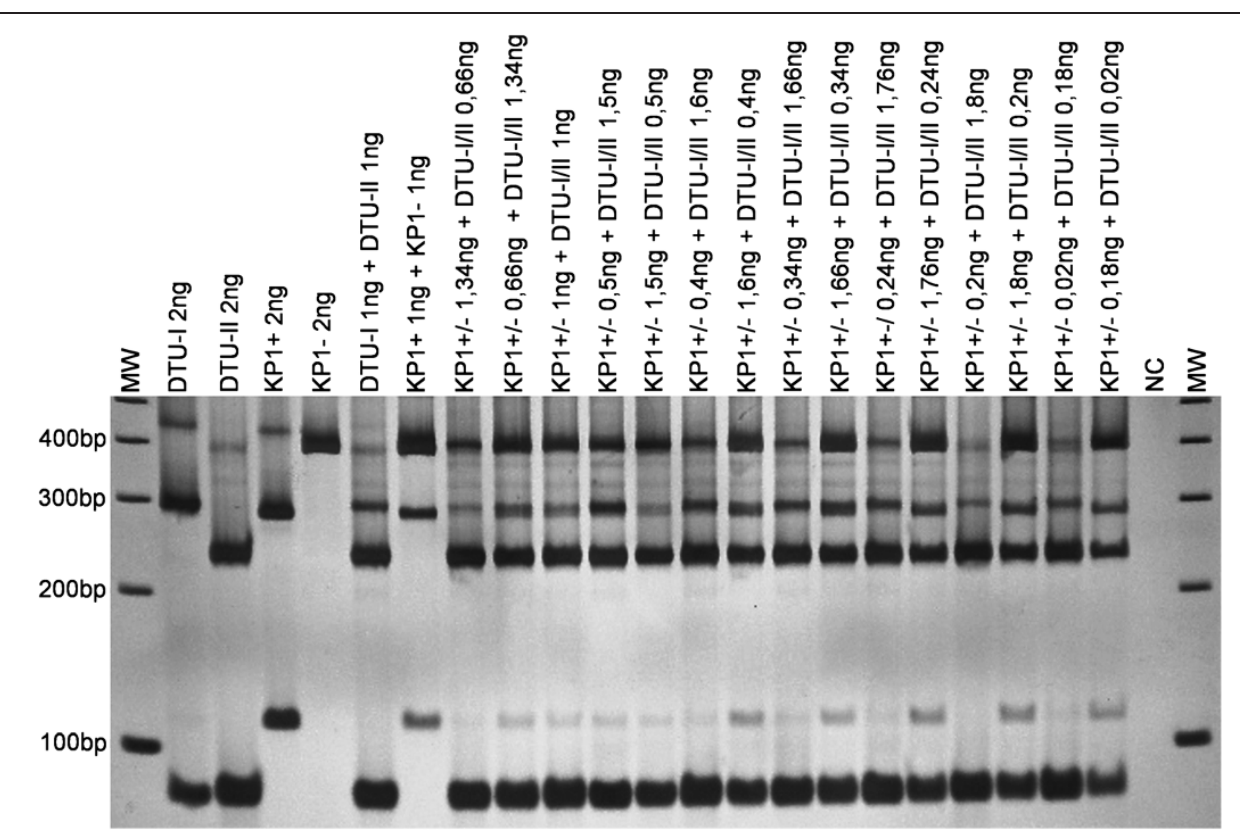

Figure 3 Profiles of COII-RFLP from DNA of each genetic group of Trypanosoma cruzi and Trypanosoma rangeli and from artificial mixtures with different ratios of DNA. Lines 1 to 4 are patterns of PCR-RFLP with Alul in 6\% polyacrylamide gel stained with silver from DNA of T. cruzi (DTU-I and DTU-II) and T. rangeli (KP1+ and KP1-), and lines 7 to 21 are artificial mixtures in the ratios 1:1 to 1:9, with amounts of DNA ranging from $2 \mathrm{ng}$ to $0.02 \mathrm{ng}$. $\mathrm{NC}=$ negative control. MW $=100 \mathrm{bp}$ DNA Ladder.

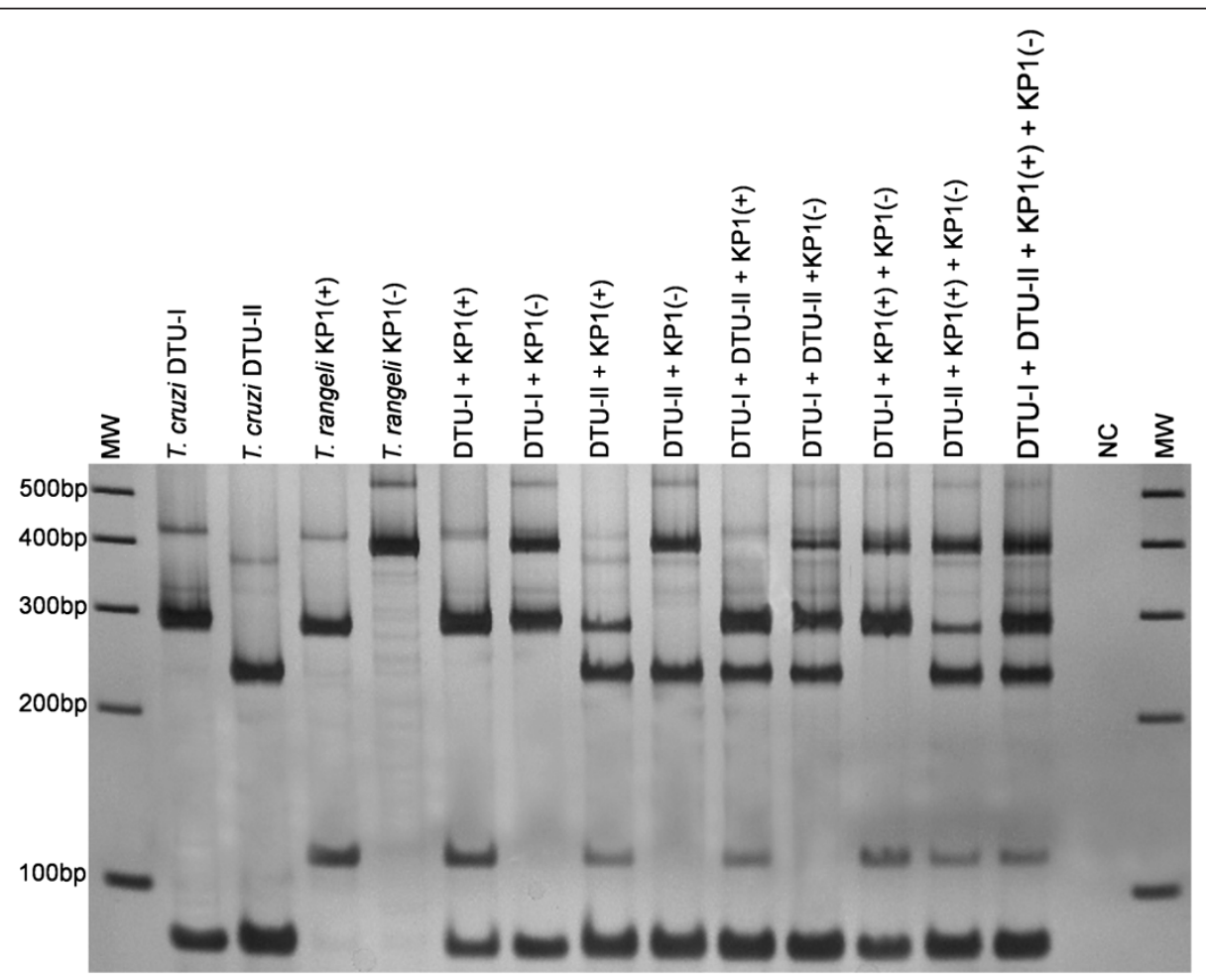

Figure 4 Profiles of COII-RFLP from Trypanosoma cruzi and Trypanosoma rangeli in triatomine intestinal tracts. Silver-stained 6\% polyacrylamide gel reveals the electrophoretic profiles of the COII-RFLP assay for detection and typing of T. rangeli (KP1+ and KP1- strains) and T. cruzi (DTU-I and DTU-II strains) in the intestinal tract of Rhodnius prolixus experimentally infected with single or mixed strains and genetic groups. MW $=100 \mathrm{bp}$ DNA Ladder (Invitrogen, USA). NC= Negative control (No DNA added). 
was present in amounts $\leq 0.4 \mathrm{ng}$, the fragments of $\sim 120 \mathrm{bp}$ from KP1+ showed a lower intensity, indicating that the amount of DNA in the sample, incomplete enzymatic digestion, or competition by enzymes of genetic groups that had larger amounts of DNA may influence the results. The absence of cleavage by AluI for the T. rangeli KP1COII gene was due to a single nucleotide polymorphism (SNP) on the enzyme recognition site, as revealed by highquality sequencing of the amplicons. This result was confirmed by COII-RFLP performed with artificial mixtures of DNA of the four major genetic groups (DTU-I, DTU-II, $\mathrm{KP} 1+$ and KP1-) in a single reaction, where KP1- was the only strain that was not cut by the enzyme. This difference allows a clear distinction of $T$. rangeli $\mathrm{KP} 1+$ from KP1strains in the COII-RFLP analysis. This is also the first analysis of a maxicircle gene from $T$. rangeli $\mathrm{kDNA}$, indicating that both maxi- and minicircles can be used for detection and genotyping strains of this taxon.

Due to the overlapping geographical distribution and the sharing of host and vector species as well as antigens by $T$. rangeli and $T$. cruzi, the existence of mixed infections in mammals and triatomines is a serious problem for diagnosis and epidemiological studies of the two parasites [2,4,11-13]. The COII-RFLP assay described here proved to be able to detect DNA and to assess the genetic groups of both parasites in artificial mixtures in vitro and in vivo in a single assay on polyacrylamide gel, because the resolution of the agarose gel to discriminate RFLP profiles was so low.

Several studies have successfully developed molecular markers to detect mixed infections, but all of them lack the ability to differentiate the genetic groups of these parasites in a simple and straightforward way, requiring the use of further molecular methods $[9,19,48]$. The inconsistency of results obtained using different markers, along with the genetic plasticity of both T. cruzi and $T$. rangeli, have led several authors to use different methods to achieve proper detection and typing of parasites in natural mixed infections in triatomine bugs [8]. Other investigators have corroborated our findings by showing that COII-RFLP detects mixed infections containing the two major DTU strains of T. cruzi (DTU-I and DTU-II) $[46,47]$ isolated from naturally infected triatomines, demonstrating the epidemiological application of this molecular marker [7], but not including the typing of the strains according to their genotypes. Hamilton et al. [49] described a fluorescence-based method for typing $T$. rangeli strains; however, this method is laborious, requires the use of DNA sequencers, and considers the existence of five different genetic groups for $T$. rangeli (A-E) [50-52] that are comprised within the KP1+ and $\mathrm{KP} 1$ - lineages. In summary, $T$. rangeli $\mathrm{KP} 1+$ strains from Vallejo et al. [21] include strains isolated from Central America, Colombia, Venezuela and Brazil in Group A, whereas KP1- includes Groups B (Brazil), C (Central America, Colombia, Peru), D (southern Brazil) and E (central Brazil) [49-52].

Considering the wide genetic variability, including intraDTU variation, and the extensive geographic ranges of the parasites studied here, the COII-RFLP was assayed with a limited but representative number of samples. The results showed that compared to the multiplex PCR targeting the rRNA gene, COII-RFLP has a clear advantage in differentiating $T$. rangeli $\mathrm{KP} 1+$ and $\mathrm{KP} 1-$ groups and simultaneously T. cruzi DTU-I and DTU-II, the most prevalent genotypes circulating in Central and South America. Thus, COII-RFLP proved to be a simple and useful tool for molecular epidemiology studies in areas where T. rangeli and T. cruzi are sympatric.

Competing interests

All authors declare that they have no competing interests.

Authors' contributions

ARNS conceived the study and conducted this work for her Master's degree. LMKD conducted this work as part of her Master's degree. MS and ECG made substantial contributions to the study design, analysis and interpretation of data. QALN, ECG and DDL carried out the molecular genetic studies, participated in the sequence alignment and drafted the manuscript. SMA and MJOT were involved in revising the manuscript for important intellectual content. MLG coordinated the work, supervised the drafting of the manuscript and contributed to the study design, analysis and interpretation of data. All authors read and approved the manuscript.

\section{Acknowledgments}

This work was supported by the Araucária Foundation (State of Paraná Research Foundation), Conselho Nacional de Desenvolvimento Científico e Tecnólogico (CNPq) and Coordenação de Aperfeiçoamento de Pessoal de Nível Superior (CAPES). To Dr. Thais Gomes Silveira Verzignassi for Leishmania spp. DNA samples, to Dr. Luiz Claudio Miletti for T. evansi and T. vivax DNA samples, and to Dr. Patrícia H. Stoco for technical discussion. D. D. Lückemeyer is the recipient of a CAPES scholarship.

\section{Author details}

${ }^{1}$ Departamento de Ciências Básicas da Saúde, Universidade Estadual de Maringá (UEM), Av. Colombo, 5790, Zona 7. CEP: 87020-900, Maringá, Paraná, Brazil. '2Departamento de Microbiologia, Imunologia e Parasitologia, Universidade Federal de Santa Catarina (UFSC), FlorianópolisSanta Catarina, Brazil. ${ }^{3}$ Departamento de Biologia Celular e Genética, Universidade Estadual de Maringá (UEM), Paraná, Brazil.

Received: 4 December 2013 Accepted: 18 December 2013 Published: 23 December 2013

\section{References}

1. Mello CB, Garcia ES, Ratcliffe NA, Azambuja P: Trypanosoma cruzi and Trypanosoma rangeli: Interplay with hemolymph components of Rhodnius prolixus. J Invertebr Pathol 1995, 65:261-268.

2. Grisard EC, Steindel M, Guarneri AA, Eger-Mangrich I, Campbell DA, Romanha AJ: Characterization of Trypanosoma rangeli strains isolated in Central and South America: An overview. Mem Inst Oswaldo Cruz 1999, 94:203-209.

3. Guhl F, Vallejo GA: Trypanosoma (Herpetosoma) rangeli Tejera, 1920 - An Updated Review. Mem Inst Oswaldo Cruz 2003, 98:435-442

4. Grisard EC, Stoco PH, Wagner G, Sincero TC, Rotava G, Rodrigues JB, Snoeijer CQ, Koerich LB, Sperandio MM, Bayer-Santos E, Fragoso SP, Goldenberg S, Triana O, Vallejo GA, Tyler KM, Dávila AM, Steindel M: Transcriptomic analyses of the avirulent protozoan parasite Trypanosoma rangeli. Mol Biochem Parasitol 2010, 174:18-25. 
5. WHO (World Health Organization): Chagas disease (American trypanosomiasis). Fact sheet No. 340. http://www.who.int/mediacentre/factsheets/fs340/en/print. html] Accessed in May, 2013

6. Steindel M, Pacheco LK, Scholl D, Soares M, Moraes MH, Eger I, Kosmann C, Sincero TC, Stoco PH, Murta SM, Carvalho-Pinto CJ, Grisard EC: Characterization of Trypanosoma cruzi isolated from humans, vectors, and animal reservoirs following an outbreak of acute human Chagas disease in Santa Catarina State, Brazil. Diagn Microbiol Infect Dis 2008, 60:25-32.

7. Abolis NG, Araújo SM, Toledo MJO, Fernandez MA, Gomes ML: Trypanosoma cruzi I-III in southern Brazil causing individual and mixed infections in humans, sylvatic reservoirs and triatomines. Acta Trop 2011, 120:167-172.

8. Ramirez LE, Lages-Silva E, Alvarenga-Franco F, Matos A, Vargas N, Fernandes O, Zingales B: High prevalence of Trypanosoma rangeli and Trypanosoma cruzi in opossums and triatomids in a formerly-endemic area of Chagas disease in Southeast Brazil. Acta Trop 2002, 84:189-198.

9. Chiurillo MA, Crisante G, Rojas A, Peralta A, Dias M, Guevara P, Añez N, Ramírez JL: Detection of Trypanosoma cruzi and Trypanosoma rangeli infection by duplex PCR assay based on telomeric sequences. Clin Diagn Lab Immunol 2003, 10:775-779.

10. Moraes MH, Guarneri AA, Girardi FP, Rodrigues JB, Eger I, Tyler KM, Steindel M, Grisard EC: Different serological cross-reactivity of Trypanosoma rangeli forms in Trypanosoma cruzi-infected patients sera. Parasit Vectors 2008, 1:20. doi:10.1186/1756-3305-1-20.

11. Sousa MA, Fonseca TS, Santos BN, Santos Pereira SM, Carvalhal C, Hasslocher MAM: Trypanosoma rangeli Tejera, 1920, in chronic Chagas' disease patients under ambulatory care at the Evandro Chagas Clinical Research Institute (IPEC-Fiocruz, Brazil). Parasitol Res 2008, 103:697-703.

12. Parada C, Villalba J, Alvarez M, Puig N, Planelles D, Ramada C, Montoro J, Roig R: Trypanosoma rangeli in a blood donor at the Valencian Blood Transfusion Centre. Vox Sang 2010, 99:193-194.

13. Grijalva MJ, Suarez-Davalos V, Villacis AG, Ocaña-Mayorga S, Dangles O: Ecological factors related to the widespread distribution of sylvatic Rhodnius ecuadoriensis populations in southern Ecuador. Parasit Vectors 2012, 5:1-17.

14. Murthy VK, Dibbern KM, Campbell DA: PCR amplification of mini-exon genes differentiates Trypanosoma cruzi from Trypanosoma rangeli. Mol Cell Prob 1992, 6:237-243.

15. Vallejo GA, Guhl F, Chiari E, Macedo AM: Species specific detection of Trypanosoma cruzi and Trypanosoma rangeli in vector and mammalian hosts by polymerase chain reaction amplification of kinetoplast minicircle DNA. Acta Trop 1999, 72:203-212

16. Fernandes O, Santos SS, Cupolillo E, Mendonça B, Derre R, Junqueira AC, Santos LC, Sturm NR, Naiff RD, Barret TV, Campbell DA, Coura JR: A mini-exon multiplex polymerase chain reaction to distinguish the major groups of Trypanosoma cruzi and T. rangeli in the Brazilian Amazon. Trans R Soc Trop Med Hyg 2001, 95:97-99.

17. Souto RP, Vargas N, Zingales B: Trypanosoma rangeli: discrimination from Trypanosoma cruzi based on a variable domain from the large subunit ribosomal RNA gene. Exp Parasitol 1999, 91:306-314.

18. Pavia PX, Vallejo GA, Montilla M, Nicholls RS, Puerta CJ: Detection of Trypanosoma cruzi and Trypanosoma rangeli infection in triatomine vectors by amplification of the histone H2A/SIRE and the sno-RNA-C11 genes. Rev Inst Med Trop São Paulo 2007, 49:23-30.

19. Morales L, Romero I, Diez H, Del Portillo P, Montilla M, Nicholls S, Puerta C: Characterization of candidate Trypanosoma rangeli small nucleolar RNA gene and its application in a PCR-based parasite detection. Exp Parasitol 2002, 102:72-80

20. Vallejo GA, Macedo AM, Chiari E, Pena SD: Kinetoplast DNA from Trypanosoma rangeli contains two distinct classes of minicircles with different size and molecular organization. Mol Biochem Parasitol 1994, 67:245-253

21. Vallejo GA, Guhl F, Carranza JC, Lozano LE, Sánchez JL, Jaramillo JC, Gualtero D, Castañeda N, Silva JC, Steindel M: kDNA markers define two major Trypanosoma rangeli lineages in Latin-America. Acta Trop 2002, 81:77-82.

22. Vallejo GA, Guhl F, Carranza JC, Moreno J, Triana O, Grisard EC: Parity between kinetoplast DNA and mini-exon gene sequences supports either clonal evolution or speciation in Trypanosoma rangeli strains isolated from Rhodnius colombiensis, $R$. pallecens and $R$. prolixus in Colombia. Infect Genet Evol 2003, 3:39-45.
23. Cuervo C, Thomas MC, López MC, Puerta CJ: Sequence polymorphism in the Trypanosoma rangeli HSP70 coding genes allows typing of the parasite KP1(+) and KP1(-) groups. Exp Parasitol 2013, 133:447-453.

24. Puerta CJ, Sincero TCM, Stoco PH, Cuervo C, Grisard EC: Comparative analysis of Trypanosoma rangeli histone $\mathrm{H} 2 \mathrm{~A}$ gene intergenic region with distinct intraspecific lineage markers. Vector Borne Zoonotic Dis 2009, 9:449-456.

25. Beltrame-Botelho IT, Gaspar-Silva D, Steindel M: Internal transcribed spacers (ITS) of Trypanosoma rangeli ribosomal DNA (rDNA): a useful marker for inter-specific differentiation. Infect Genet Evol 2005, 5:27-28.

26. Dias FBS, Diotaiuti L, Romanha AJ, Bezerra CM, Machado EMM: First report on the occurrence of Trypanosoma rangeli Tejera, 1920 in the state of Ceará, Brazil, in naturally infected triatomine Rhodnius nasutus Stal, 1859 (Hemiptera, Reduviidae, Triatominae). Mem Inst Oswaldo Cruz 2007, 102:643-645.

27. Bosseno MF, Telleria J, Vargas F: Trypanosoma cruzi: study of the distribution of two widespread clonal genotypes in Bolivian Triatoma infestans vectors shows a high frequency of mixed infections. Exp Parasitol 1996, 83:275-282.

28. Barnabé C, Brisse S, Tibayrenc M: Population structure and genetic typing of Trypanosoma cruzi, the agent of Chagas disease: a multilocus enzyme electrophoresis approach. Parasitology 2000, 120:513-526.

29. Yeo M, Acosta N, Llevellyn M, Sánchez H, Adamson S, Miles GA, López E, González N, Patterson JS, Gaunt MW, Arias AR, Miles MA: Origins of Chagas disease: Didelphis species are natural hosts of Trypanosoma cruzi I and armadillos hosts of Trypanosoma cruzi II, including hybrids. Int J Parasitol 2005, 35:225-233.

30. Freitas JM, Pinto LA, Pimenta JR, Bastos-Rodrigues L, Gonçalves VF, Teixeira SMR, Chiari E, Junqueira ACV, Fernandes O, Macedo AM, Machado CR, Pena Sérgio DJ: Ancestral genomes, sex, and the population structure of Trypanosoma cruzi. PLoS Pathog 2006, 2:e24.

31. Llewellyn MS, Lewis MD, Acosta N, Yeo M, Carrasco HJ, Segovia M, Vargas J, Torrico F, Miles MA, Gaunt MW: Trypanosoma cruzi llc: phylogenetic and phylogeographic insights from sequence and microsatellite analysis and potential impact on emergent Chagas disease. PLoS Negl Trop Dis 2009, 3:e510.

32. Marcili A, Valente VC, Valente SA, Junqueira ACV, da Silva Maia F, Pinto AYN, Naiff RD, Campaner M, Coura JR, Camargo EP, Miles MA, Teixeira MMG: Trypanosoma cruzi in Brazilian Amazonia: Lineages $\mathrm{TCl}$ and TClla in wild primates, Rhodnius spp. and in humans with Chagas disease associated with oral transmission. Int J Parasitol 2009a, 39:615-623.

33. Monteiro WM, Magalhães LK, Santana Filho FS, Borborema M, Silveira H, Barbosa MD: Trypanosoma cruzi Tclll/Z3 genotype as agent of an outbreak of Chagas disease in the Brazilian Western Amazonia. Trop Med Int Health 2010, 15:1049-1051.

34. Burgos JM, Diez M, Vigliano C, Bisio M, Risso M, Duffy T, Cura C, Brusses B, Favaloro L, Leguizamon MS, Lucero RH, Laguens R, Levin MJ, Favaloro R, Schijman AG: Molecular identification of Trypanosoma cruzi discrete typing units in end-stage chronic Chagas heart disease and reactivation after heart transplantation. Clin Infect Dis 2010, 51:485-495.

35. Zingales B, Andrade SG, Briones MR, Campbell DA, Chiari E, Fernandes O, Guhl F, Lages-Silva E, Macedo AM, Machado CR, Miles MA, Romanha AJ, Sturm NR, Tibayrenc M, Schijman AG, Second Satellite Meeting: A new consensus for Trypanosoma cruzi intraspecific nomenclature: second revision meeting recommends Tcl to TcVI. Mem Inst Oswaldo Cruz 2009, 104:1051-1054.

36. Zingales B, Miles MA, Campbell DA, Tibayrenc M, Macedo AM, Teixeira MM, Schijman AG, Llewellyn MS, Lages-Silva E, Machado CR, Andrade SG, Sturm NR: The revised Trypanosoma cruzi subspecific nomenclature: rationale, epidemiological relevance and research applications. Infect Genet Evol 2012, 12:240-253.

37. Zumaya-Estrada FA, Messenger LA, Lopez-Ordonez T, Lewis MD, Flores-Lopez CA, Martínez-lbarra AJ, Pennington PM, Cordon-Rosales C, Carrasco HV, Segovia M, Miles MA, Llewellyn MS: North American import? Charting the origins of an enigmatic Trypanosoma cruzi domestic genotype. Parasit Vectors 2012, 5:226-234.

38. Sturm NR, Vargas NS, Westenberger SJ, Zingales B, Campbell DA: Evidence for multiple hybrid groups in Trypanosoma cruzi. Int J Parasitol 2003, 33:269-279.

39. Westenberger SJ, Barnabé C, Campbell DA, Sturm NR: Two hybridization events define the population structure of Trypanosoma cruzi. Genetics 2005, 171:527-543. 
40. Marcili A, Lima L, Cavazzana M, Junqueira AC, Veludo HH, Maia da Silva F, Campaner M, Paiva F, Nunes VL, Teixeira MM: A new genotype of Trypanosoma cruzi associated with bats evidenced by phylogenetic analyses using SSU rDNA, cytochrome $b$ and Histone H2B genes and genotyping based on ITS1 rDNA. Parasitology 2009, 136:641-655.

41. Macedo AM, Martins MS, Chiari E, Pena SD: DNA Fingerprinting of Trypanosoma cruzi: A new tool for characterization of strains and clones. Mol Biochem Parasitol 1992, 55:147-154.

42. Del Sal G, Manfioletti G, Schneider C: The CTAB-DNA precipitation method: a common mini-scale preparation of template DNA from phagemids, phages or plasmids suitable for sequencing. Biotechniques 1989, 7:514-520.

43. Ewing B, Hillier L, Wendl MC, Green P: Base-calling of automated sequencer traces using Phred. I. Accuracy assessment. Genome Res 1998, 8:175-185.

44. Thompson JD, Gibson TJ, Higgins DG: Multiple sequence alignment using ClustalW and ClustalX. Curr Protoc Bioinformatics Chapter 2002. Unit 2.3. doi: 10.1002/0471250953.bi0203s00.

45. Hall TA: BioEdit: a user-friendly biological sequence alignment editor and analysis program for Windows 95/98/NT. Nucleic Acids Symp Ser 1999, 41:95-98.

46. Nunes LR, Carvalho MR, Buck GA: Trypanosoma cruzi strains partition into two groups based on the structure and function of the spliced leader RNA and rRNA gene promoters. Mol Biochem Parasitol 1997, 86:211-224.

47. Souto RP, Fernandes O, Macedo AM, Campbell DA, Zingales B: DNA markers define two major phylogenetic lineages of Trypanosoma cruzi. Mol Biochem Parasitol 1996, 83:141-152.

48. Higuera SL, Guhl F, Ramírez JD: Identification of Trypanosoma cruzi Discrete Typing Units (DTUs) through the implementation of a HighResolution Melting (HRM) genotyping assay. Parasit Vectors 2013, 6:112.

49. Hamilton PB, Lewis MD, Cruickshank C, Gaunt MW, Yeo M, Llewellyn MS, Valente SA, Maia da Silva F, Stevens JR, Miles MA, Teixeira MM: Identification and lineage genotyping of South American trypanosomes using fluorescent fragment length barcoding. Infect Genet Evol 2011, 11:44-51.

50. da Silva Maia F, Noyes H, Campaner M, Junqueira AC, Coura JR, Añez N, Shaw JJ, Stevens JR, Teixeira MM: Phylogeny, taxonomy and grouping of Trypanosoma rangeli isolates from man, triatomines and sylvatic mammals from widespread geographical origin based on SSU and ITS ribosomal sequences. Parasitology 2004b, 129:549-561.

51. da Silva Maia F, Junqueira AC, Campaner M, Rodrigues AC, Crisante G, Ramirez LE, Caballero ZC, Monteiro FA, Coura JR, Añez N, Teixeira MM: Comparative phylogeography of Trypanosoma rangeli and Rhodnius (Hemiptera: Reduviidae) supports a long coexistence of parasite lineages and their sympatric vectors. Mol Ecol 2007, 16:3361-3373.

52. da Silva Maia F, Marcili A, Lima L, Cavazzana MJ, Ortiz PA, Campaner M, Takeda GF, Paiva F, Nunes VL, Camargo EP, Teixeira MM: Trypanosoma rangeli isolates of bats from Central Brazil: genotyping and phylogenetic analysis enable description of a new lineage using spliced-leader gene sequences. Acta Trop 2009, 109:199-207.

doi:10.1186/1756-3305-6-363

Cite this article as: de Sá et al:: Cytochrome oxidase subunit 2 gene allows simultaneous detection and typing of Trypanosoma rangeli and Trypanosoma cruzi. Parasites \& Vectors 2013 6:363.

\section{Submit your next manuscript to BioMed Central and take full advantage of:}

- Convenient online submission

- Thorough peer review

- No space constraints or color figure charges

- Immediate publication on acceptance

- Inclusion in PubMed, CAS, Scopus and Google Scholar

- Research which is freely available for redistribution

Submit your manuscript at www.biomedcentral.com/submit 